\title{
Testing alternative vicariance scenarios in Western Mediterranean discoglossid frogs
}

\author{
Lutz Fromhage, ${ }^{a}$ Miguel Vences, ${ }^{\mathrm{b}}$ and Michael Veith ${ }^{\mathrm{a}, *}$ \\ a Institut für Zoologie, Universität Mainz, Saarstraße 21, D-55099 Mainz, Germany \\ ${ }^{\mathrm{b}}$ Institute for Biodiversity and Ecosystem Dynamics, Zoological Museum, University of Amsterdam, The Netherlands
}

Received 5 May 2003; revised 11 July 2003

\begin{abstract}
Dated molecular phylogenies are often used to interpret evolutionary history with respect to paleogeographic events. Where more than one interpretation is possible, it is desirable but difficult to assess the alternatives in an objective manner. The present work demonstrates a formalized method for testing molecular clock calibrations and biogeographic scenarios based on them. We assessed the plausibility of several previously published biogeographic hypotheses, using the frog genera Alytes, Discoglossus, and Bombina as model groups. Our data set comprised ca. 900 bp of partial mitochondrial 16S and 12S rRNA gene sequences (both genes evolved in a clock-like manner across genera) from nearly all the species and subspecies in the three genera. We tested several calibrations of a molecular clock, which resulted in competing temporal settings for the evolution of taxa. Although only one scenario was in complete accordance with paleogeographic data, statistical testing did not reject the alternatives. Limitations encountered with the present approach may be overcome by more comprehensive analyses in future.
\end{abstract}

(C) 2003 Elsevier Inc. All rights reserved.

Keywords: Phylogeny; Molecular clock; 16S; 12S; Amphibia; Discoglossidae; Bombinatoridae; Paleobiogeography; Fisher's exact test

\section{Introduction}

Estimating dates of lineage divergence is a common aim in molecular phylogenetic studies (e.g., Heckman et al., 2001; Hedges et al., 1996; Wray et al., 1996). If molecular distances accumulate at a uniform rate across different taxa, a known date of divergence for a given pair of taxa can be used to estimate divergence times for other nodes within a molecular phylogeny (Zuckerkandl and Pauling, 1962, 1965). To account for uncertainties associated with the assumption of rate constancy, Hillis et al. (1996) recommended that calibrations of such a "molecular clock" should refer to a regression function based on multiple calibration points. More recently, methods have been developed in a framework of likelihood and Bayesian theory that aim to relax the

\footnotetext{
${ }^{*}$ Corresponding author. Fax: +49-6131-3923731.

E-mail addresses: lutzfromhage@web.de (L. Fromhage), vences@science.uva.nl (M. Vences), michael@oekologie.biologie. uni-mainz.de (M. Veith).
}

assumption of rate constancy by modeling the evolution of rates between multiple calibration points (Rambaut and Bromham, 1998; Sanderson, 1997; Thorne et al., 1998).

All of these methods can be expected to work well where reliable a priori information on divergence times is available. Unfortunately, this criterion will rarely be fulfilled where historical processes are concerned. Potential calibration points often refer to hypotheses, which may or may not be true. If both true and flawed calibration points are incorporated into one calibration, severely biased or confounded results will be the likely outcome. In the present study, we tried to account for this problem by using individual calibration points separately to establish independent calibrations. Based on the assumption that a correct calibration should yield plausible divergence time estimates, we developed a biogeographic scenario for each calibration and assessed its fit to the paleogeographic record. We applied a formalized procedure to evaluate the plausibility of each biogeographic scenario, thereby assessing the degree of confidence that should be placed in the respective cali- 
brations. Our molecular data set from three clades of frogs showed no significant signal of rate heterogeneity among lineages, which was an important prerequisite for this approach.

The Mediterranean region is well suited for testing biogeographic hypotheses. It harbors a rich endemic fauna and flora that has evolved through a complex interplay of geological (e.g., orogenic) and paleoclimatic vicariance events (Blondel and Aronson, 1999). The emergence of mountain chains and sea straits directly isolated populations, while islands and peninsulas provided important refugia during phases of habitat retraction (see Appendix A for a compilation of relevant paleogeographic events).

Dispersal and vicariance have been identified as the principal mechanisms responsible for the formation of biogeographic patterns (e.g., Stace, 1989). Amphibians are favorable model organisms to study the effects of vicariance, since their dispersal across marine barriers is limited due to a low salinity tolerance (Stebbins and Cohen, 1995). The discoglossid frog genera Discoglossus and Alytes are distributed throughout the Western Mediterranean, including the European and African continents and several islands (Fig. 1). Both genera comprise a set of endemic species and subspecies, and several independent biogeographic explanations for their evolution have been published.

Lanza (1973, cited in Lanza et al., 1987) explained the differentiation of all Discoglossus taxa by isolation of their ancestor in separate glacial refuges (3.4-0.01 million years ago = MYA; see Appendix A for paleogeographic references), a view that was contradicted by later studies when genetic data became available. The hypotheses of Capula et al. (1985) referred to much older vicariance events. They explained the basal split within Discoglossus by the isolation of Corsica from continental Europe at the end of the Messinian Salinity Crisis (5.33 MYA) or, alternatively, by the separation of the Corsica-Sardinia microplate from the continent (29 MYA). Furthermore, Busack (1986) suggested a Messinian (5.33 MYA) separation of Iberian and African Discoglossus, while García-París and Jockusch (1999) explained the divergence of the two Iberian taxa Discoglossus galganoi and Discoglossus jeanneae by the reopening of the Betic sea strait (ca. 7 MYA). In their scenario of Alytes evolution, Arntzen and García-París (1995, 1997) used the Messinian Salinity Crisis (5.33 MYA) to explain a split of Balearic and Iberian lineages. Alternative hypotheses concerning Discoglossus and Alytes evolution were given by Vences and Glaw (1996) and Altaba (1997). According to Szymura (1993), the differentiation of European Bombina, the third genus in this study, was accounted for by its isolation in glacial refuges (3.4-0.01 MYA) in south and south-east Europe (also see Arntzen, 1978; Mertens, 1928). No consensus has yet been reached regarding the relationships between

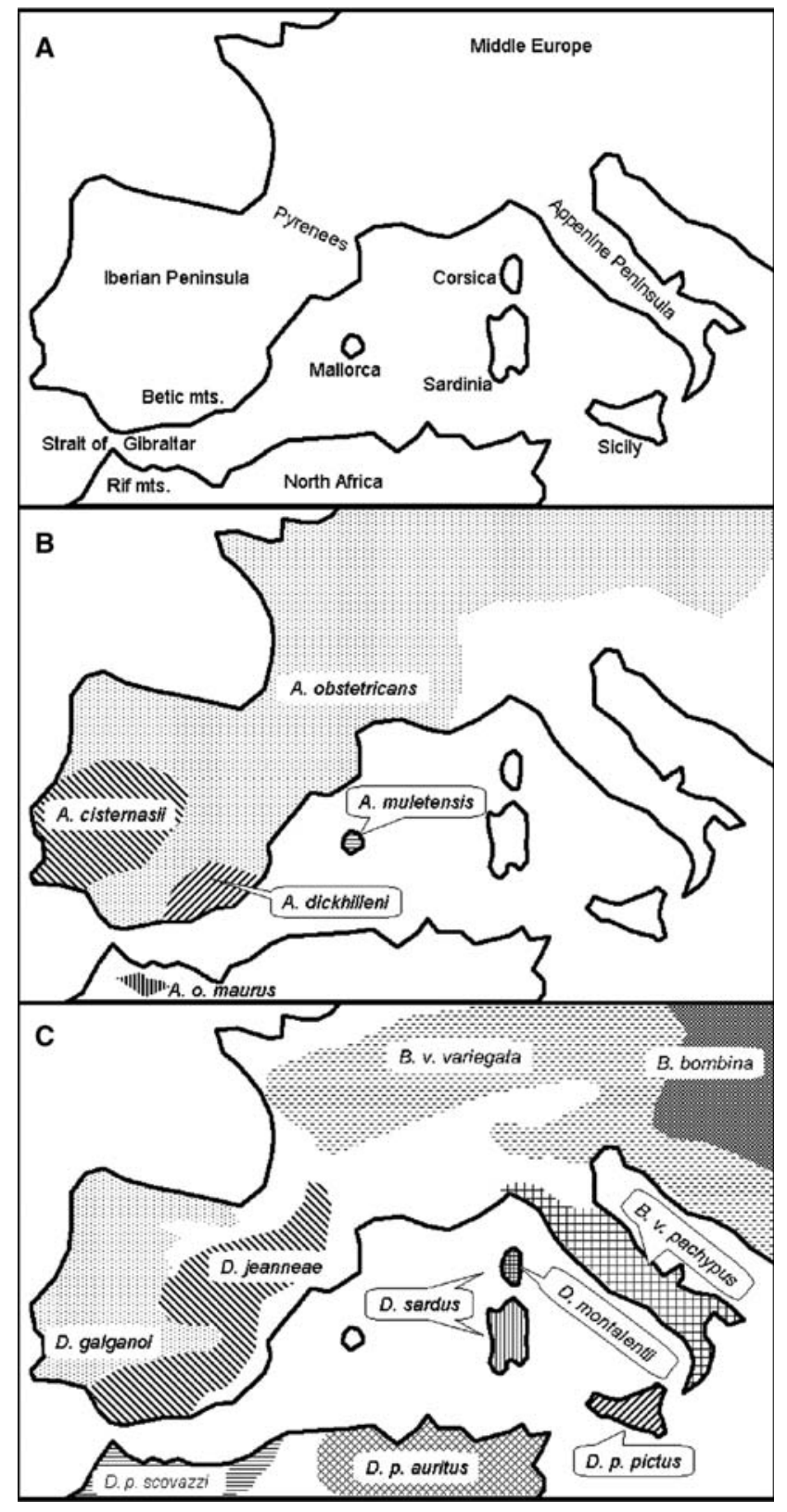

Fig. 1. Present distribution of discoglossid frogs in the Western Mediterranean: (A) important landmarks; (B) distribution of Alytes (simplified after Arntzen and García-París, 1995); (C) distribution of Discoglossus and Bombina (simplified after García-París and Jockusch, 1999; Gasc et al., 1997).

Discoglossus, Alytes, and Bombina, with conflicting evidence from morphological (Ford and Cannatella, 1993) and molecular analyses (Hay et al., 1995).

Here, we used several current biogeographic hypotheses for independent calibrations of a molecular clock. This way, we were able to (i) test for congruence between hypotheses that have been independently put forward for individual genera, (ii) find a unifying hypothesis that includes all genera, and most importantly, (iii) integrate information across genera to assess the consistence of 
calibration attempts and scenarios with the paleogeographic record. The latter has implications for biogeographic hypothesizing and molecular clock issues.

\section{Materials and methods}

\subsection{Samples}

We studied 51 specimens that comprise almost all currently acknowledged species and subspecies of Alytes, Discoglossus, and Western Palearctic Bombina (Appendix B). Only the eastern Iberian Alytes obstetricans almogavarii was not represented. Based on an interfamilial anuran phylogeny (Hay et al., 1995), we chose several taxa for hierarchical outgroup comparison: Pelobates cultripes, Leiopelma hamiltoni, Pipa parva, Rana temporaria, and Bufo asper. Sequence data of $R$. temporaria (12S: AF 124103 and 16S: AF124135), B. asper (12S: U52733 and 16S: AF 124109), and L. hamiltoni (12S: X86241 and 16S: X86309, X86275) were obtained from GenBank. DNA from other taxa was extracted from either fresh or ethanol-preserved tissue samples.

\subsection{DNA sequencing}

DNA was extracted using the "High Pure PCR Template Preparation Kit" (Roche Diagnostics) following standard protocols. Two mitochondrial gene fragments were amplified using the following primers. GenBank Accession Nos. are given in Appendix B.

16S: 16SA (light chain; 5'-CGC CTG TTT ATC AAA AAC AT-3') and 16SB (heavy chain; 5'-CCC GTC TGA ACT CAG ATC ACG T-3') of Palumbi et al., 1991) were used to amplify a ca. $580 \mathrm{bp}$ section of the mitochondrial 16S rRNA gene homologous to positions 3976-4554 of the Xenopus laevis mitochondrial genome (GenBank Accession No. M10217; Roe et al., 1985).

12S: 12SA-L (light chain: 5'-AAA CTG GGA TTA GAT ACC CCA CTA T-3') and 12SB-H (heavy chain: 5'-GAG GGT GAC GGG CGG TGT GT-3') of Goebel et al. (1999) were used to amplify a ca. $490 \mathrm{bp}$ section of the mitochondrial 12S rRNA gene homologous to positions 2510-2997 of the $X$. laevis mitochondrial genome (Roe et al., 1985).

PCR products were purified using the "High Pure PCR Product Purification Kit" (Roche diagnostics). We sequenced single-stranded fragments on an ABI 377 automatic sequencer using standard protocols.

Sequences were aligned using Clustal X (Thompson et al., 1997). Some hypervariable regions were too variable to be aligned across different genera. We therefore compiled four different alignments (a-d) according to different questions: (a) all three genera, with hypervariable regions omitted, (b) genus Discoglossus, (c) genus Alytes, and (d) genus Bombina. We used alignment (a) to test and apply a molecular clock across genera. We used alignments (b)-(d), with greater numbers of base positions included (see Table 2), to achieve the best possible resolution within genera. All alignments are available from the authors upon request.

\subsection{Phylogenetic analyses}

Among identical haplotypes, we excluded all but one from phylogenetic analyses. We investigated the degree of heterogeneity between the two gene fragments using the incongruence length differential (ILD) test of (Farris et al., 1994; see also Huelsenbeck et al., 1996; Whelan et al., 2001) as implemented in PAUP*, version 4.0b10 (Swofford, 2001) with settings as follows: 100 replicates, heuristic search using the tree bisection and reconnection (TBR) branch swapping algorithm. This test is used to determine whether significantly more evolutionary steps are required when data partitions are pooled rather than analyzed separately. Prior to model assessment, we performed $\chi^{2}$ tests for base distribution across sequences in order to rule out non-homogeneous base compositions. Using a hierarchical likelihood ratio test, we tested the goodness-of-fit of nested substitution models for homogeneous data partitions of ingroup taxa. Modeltest version 3.04 (Posada and Crandall, 1998) was used to calculate the test statistic $\delta=2 \log \Lambda$ with $\Lambda$ being the ratio of the likelihood of the null model divided by the likelihood of the alternative model (for details see Huelsenbeck and Crandall, 1997). We used the chosen models for further analyses.

Data were subjected to three different methods of phylogenetic reconstruction: (i) neighbor-joining (NJ) (Saitou and Nei, 1987) using the selected substitution model; (ii) maximum parsimony (MP) with gaps excluded (following Swofford et al., 1996); transitions and transversions given equal weight (see Broughton et al., 2000; Rosenberg and Kumar, 2001), heuristic search with the TBR branch swapping algorithm; and (iii) maximum likelihood (ML) based on the selected substitution model. NJ and MP analyses were run with PAUP*, version 4.0b10 (Swofford, 2001). We tested the robustness of the NJ and MP tree topologies using the bootstrap method (Felsenstein, 1985), with 2000 replicates each (Hedges, 1992). Following Hillis and Bull (1993), we used bootstrap values as a measure of the probability that a recovered group represents a true clade. Due to computational constraints, the support values for ML were calculated by quartet puzzling (QP) with 2000 puzzling steps, using TREE-PUZZLE (Schmidt et al., 2000).

\subsection{Test for substitution rate constancy}

We performed a test for substitution rate constancy (molecular clock test) using TREE-PUZZLE (Schmidt 
et al., 2000) on alignment (a) with $P$. cultripes as the outgroup. This test compares the log-likelihood of the most likely tree with and without a molecular clock enforced. We used the Tamura-Nei substitution model (Tamura and Nei, 1993) with the gamma distribution shape parameter set to $\alpha=0.54$ according to the Modeltest result. Base frequencies $\left(\pi_{\mathrm{A}}=29.9 \%, \pi_{\mathrm{C}}=26.5 \%\right.$, $\left.\pi_{\mathrm{G}}=22.3 \%, \pi_{\mathrm{T}}=21.4 \%\right)$ were estimated from the data.

\subsection{Molecular distances and their confidence intervals}

Molecular distances for the application of a molecular clock were computed between group means with standard deviations for 2000 bootstrap replications using MEGA version 2.1 (Kumar et al., 2001). Again, alignment (a) and the Tamura-Nei substitution model with $\alpha=0.54$ were used. In this context, the bootstrap approach provides an estimate that can account for stochastic variation in distance evolution (Nei and Kumar, 2000), which is thought to be a major source of error in molecular clock applications (Hillis et al., 1996). We calculated $95 \%$ confidence intervals for genetic distances, and corresponding divergence time estimations, as the mean $\pm 1.96 \mathrm{SD}$. Although it is thought to be impossible to satisfy all the conditions of a perfect molecular clock model in the real world (Hillis et al., 1996), use of this method is justified in the present case because (i) there was no significant signal for rate heterogeneity among taxa (see results) and (ii) potential inaccuracy of confidence limits would affect all alternative hypotheses in our comparative approach. The comparison among hypotheses would thus still be valid.

\subsection{Test for plausibility of scenarios}

We used the following formalized procedure to assess the plausibility of alternative paleobiogeographic scenarios.

1. Phylogenetic splits. Identify splits that are suitable for biogeographic interpretation. These are well-supported clades that (i) split into two well-supported subclades or (ii) represent polytomies that can be interpreted as subsequent, temporally close splits.
We considered nodes with NJ, MP, and QP support values of $>70 \%$ as well supported (Hillis and Bull, 1993; but see limitations listed therein). Several splits narrowly missed the $70 \%$ criterion, but were still considered suitable for interpretation as they were in accordance with previously published and well-supported allozyme and immunological data (split 4 in Table 3: Capula et al., 1985; splits 7 and 8: Arntzen and García-París, 1995, 1997; split 9: Maxson and Szymura, 1979, 1984; Szymura, 1988).

2. Paleogeographic events. Identify paleogeographic events that may have caused vicariance of the taxa in question. Such events are the flooding of land bridges, disruption of geologic formations, the rise of mountain chains, or climatic deterioration.

See Appendix A for a compilation of relevant events in the context of this study.

3. Molecular clock. Select events that are suitable for calibration of a molecular clock. These are well-dated paleogeographic events that can explain phylogenetic splits in a spatially plausible way (see below for the assessment of spatial plausibility). Date these splits a priori and use each of them to establish an independent calibration of a molecular clock. For each calibration, calculate divergence times and confidence intervals across the remaining splits. We used four alternative calibrations with reference to previously published biogeographic hypotheses (Table 1).

4. Temporal compatibility. For each estimated divergence time derived from step (3), identify temporally matching paleogeographic events within its confidence limits.

5. Spatial plausibility. Where estimated divergence times are matched by paleogeographic events, consider the vicariant areas and compare them to the present-day distribution of the lineages in question. Accept plausibility where (i) representatives of those lineages live near or within the vicariant ranges and (ii) dispersal events that have to be assumed to explain present species ranges are deemed possible in the light of paleogeographic data.

6. Internal consistency. While each split was considered separately under (4) and (5), interpretations for

Table 1

Paleogeographic events and phylogenetic splits used for molecular clock calibrations

\begin{tabular}{|c|c|c|c|}
\hline No. & Paleogeographic event & Time (MYA) & Phylogenetic split with reference \\
\hline I & End of the Messinian Salinity Crisis & 5.33 (Krijgsman et al., 1999) & $\begin{array}{l}\text { D. p. scovazzi-D. galganoilD. jeanneae } \\
\text { (see Busack, 1986) }\end{array}$ \\
\hline II & End of the Messinian Salinity Crisis & 5.33 (Krijgsman et al., 1999) & $\begin{array}{l}\text { D. montalentii-other Discoglossus } \\
\text { (Capula et al., 1985) }\end{array}$ \\
\hline III & End of the Messinian Salinity Crisis & 5.33 (Krijgsman et al., 1999) & $\begin{array}{l}\text { A. dickhilleni-A. muletensis-A. o. maurus } \\
\text { (see Arntzen and García-París, 1995) }\end{array}$ \\
\hline IV & $\begin{array}{l}\text { Separation of the Corsica-Sardinia } \\
\text { microplate from the continent }\end{array}$ & 29 (Bellon et al., 1977; Orsini et al., 1980) & $\begin{array}{l}\text { D. montalentii-other Discoglossus } \\
\text { (Capula et al., 1985) }\end{array}$ \\
\hline
\end{tabular}

Dates are given in million years ago (MYA). 
different splits must be mutually compatible to be included in one biogeographic scenario. For each calibration, identify the maximum number of vicariance explanations that can be included in a scenario without internal contradictions. Ensure that (i) the temporal sequence of proposed vicariance events matches the cladogenetic sequence of splits and (ii) spatial interpretations of individual splits do not contradict each other. If potential explanations for two splits are mutually exclusive, one split has to be declared "unexplained." It makes no difference which explanation is dismissed, since the statistical test used in step (7) considers only the total number of explained and unexplained splits.

7. Statistical testing. Use Fisher's exact test to determine in pairwise comparisons whether the best-fitting scenario explains significantly more splits than its alternatives. When comparing two scenarios, consider the null hypothesis $\left(\mathrm{H}_{0}\right)$ that neither alternative is true. In this case split events may be explained by chance, which leads to the prediction that explained split events should be randomly distributed across scenarios. According to the alternative hypothesis, one scenario does at least partly correspond to the historical truth. Hence an increased number of explained split events can be predicted in this scenario. Fisher's two-tailed exact test yields the exact probability $P$ that a difference at least as extreme as the one observed between two scenarios occurs by chance, given the total numbers of explained and unexplained splits. Adjust the critical $P$-level for multiple testing by a sequential Bonferroni correction and reject $\mathrm{H}_{0}$, where $P<0.05$.

\section{Results}

The test for partition homogeneity revealed no conflicting phylogenetic signals between the two gene fragments ( $P$ values of alignments were as follows: $P_{(\mathrm{a})}=0.57$; $\left.P_{(\mathrm{b})}=0.5 ; P_{(\mathrm{c})}=0.24 ; P_{(\mathrm{d})}=0.33\right)$. Consequently, both gene fragments were combined in all alignments for further analyses. Standard sequence statistics for all alignments are given in Table 2. Transitions (ti) by far outnumbered transversions (tv), indicating only weak saturation of transitions in the chosen genes, which was confirmed by visual inspection of a plot of uncorrected distances for transitions as a function of $\operatorname{TrN}$ distances (data not shown). We accepted this minor degree of saturation as background noise in all analyses. Nucleotide frequencies did not differ significantly from a homogeneous distribution. Substitution models as chosen by hierarchical likelihood ratio tests are given in Table 2.

\subsection{Phylogenetic relationships}

Monophyly of genera was confirmed by support values of $>95 \%$ each (Figs. 2-5), with lack of well-supported resolution of their inter-generic relations. The genus Discoglossus showed a well-resolved position of Discoglossus montalentii standing basal to all other species (Fig. 3). Sister-group relations appeared between Discoglossus pictus scovazzi and a D. galganoilD. jeanneae clade, and between Discoglossus sardus and an unresolved Discoglossus pictus pictus/Discoglossus pictus auritus clade. Thus, Discoglossus pictus was non-monophyletic. Within Alytes, a basal split separated Alytes

Table 2

Standard sequence statistics, tests for homogeneity of base frequencies among ingroup taxa $\left(\chi^{2}\right.$-test), and substitution models as chosen using hierarchical likelihood ratio tests for four different alignments $(\mathrm{a}=$ all three genera, $\mathrm{b}=$ Discoglossus, $\mathrm{c}=$ Alytes, $\mathrm{d}=$ Bombina $)$; bp, number of analyzed base pairs (including gaps); VS, variable sites; PI, parsimony-informative sites; $\pi_{\mathrm{A}}, \pi_{\mathrm{G}}, \pi_{\mathrm{C}}, \pi_{\mathrm{T}}=$ empirical base frequencies; ti/tv ratios are given for ingroup taxa only; $\mathrm{I}=$ proportion of invariable sites, $\alpha=$ gamma shape parameter

\begin{tabular}{|c|c|c|c|c|}
\hline & Alignment (a) & Alignment (b) & Alignment (c) & Alignment (d) \\
\hline \multicolumn{5}{|c|}{ Standard sequence statistics } \\
\hline bp & 868 & 909 & 879 & 927 \\
\hline VS & 343 & 217 & 206 & 179 \\
\hline PI & 233 & 105 & 73 & 78 \\
\hline$\pi_{\mathrm{A}}$ & 0.300 & 0.299 & 0.296 & 0.304 \\
\hline$\pi_{\mathrm{G}}$ & 0.222 & 0.218 & 0.220 & 0.218 \\
\hline$\pi_{\mathrm{C}}$ & 0.262 & 0.264 & 0.273 & 0.262 \\
\hline$\pi_{\mathrm{T}}$ & 0.216 & 0.219 & 0.211 & 0.216 \\
\hline ti/tv ratio & 3.142 & 4.426 & 3.349 & 3.132 \\
\hline \multicolumn{5}{|l|}{ Homogeneity test } \\
\hline$\chi^{2}$-value & 11.21 & 0.95 & 1.12 & 3.15 \\
\hline Degrees of freedom & 102 & 36 & 21 & 42 \\
\hline$p$ value & 1 & 1 & 1 & 1 \\
\hline \multicolumn{5}{|l|}{ Substitution model test } \\
\hline Chosen model & $\begin{array}{l}\operatorname{TrN}+I+G \text { (Tamura } \\
\text { and Nei, 1993) }\end{array}$ & $\begin{array}{l}\text { HKY + I (Hasegawa } \\
\text { et al., 1985) }\end{array}$ & $\begin{array}{l}\text { HKY + I (Hasegawa } \\
\text { et al., 1985) }\end{array}$ & $\begin{array}{l}\text { HKY }+I+G \text { (Hasegawa } \\
\text { et al., 1985) }\end{array}$ \\
\hline$I$ & 0.5457 & 0.8293 & 0.8506 & 0.8105 \\
\hline$\alpha$ & 0.5394 & - & - & 0.7425 \\
\hline
\end{tabular}




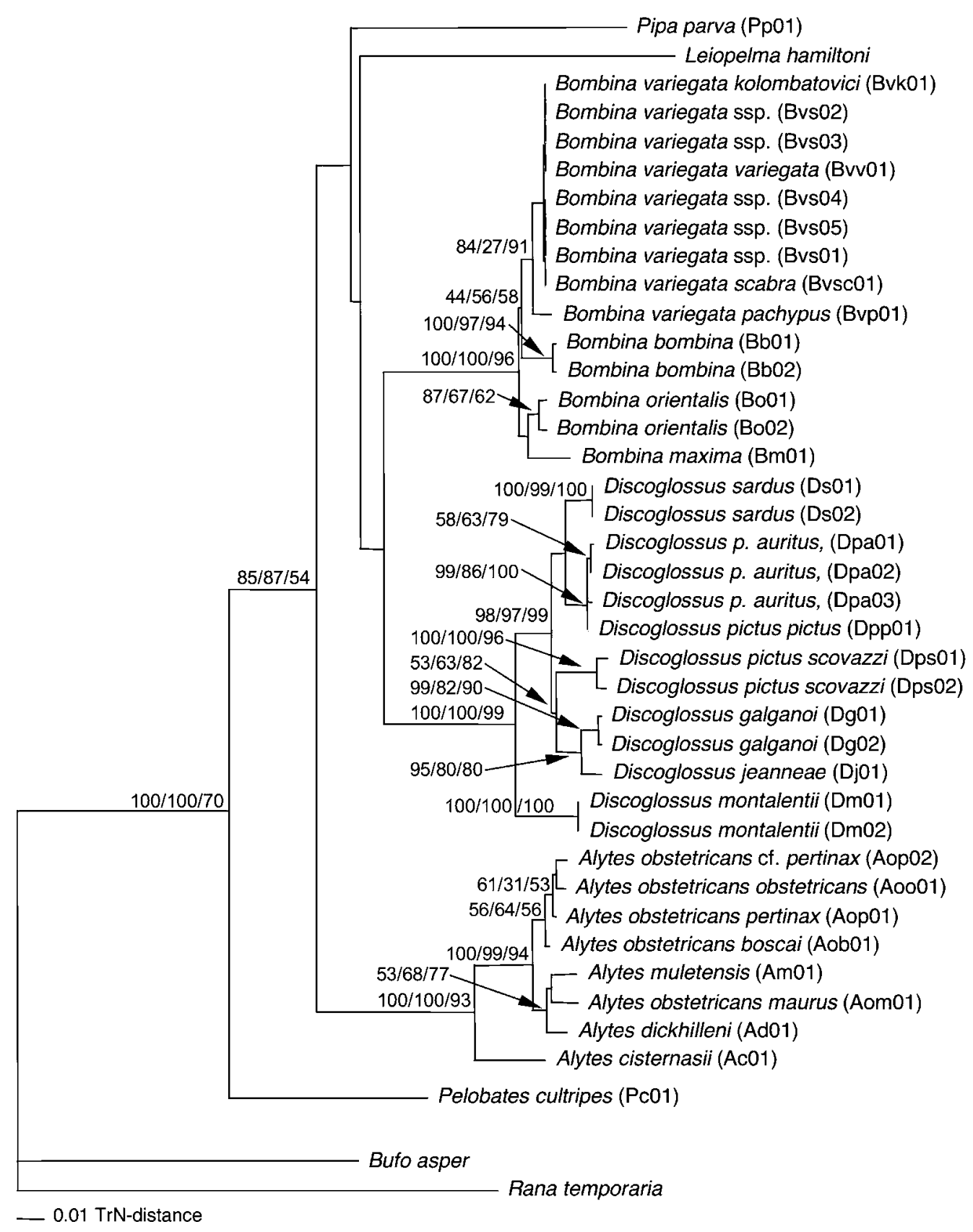

Fig. 2. NJ tree based on $868 \mathrm{bp}$ of $16 \mathrm{~S}$ and $12 \mathrm{~S}$ (alignment a) with Rana temporaria defined as the outgroup; NJ/MP/QP support values (\%) for 2000 bootstrap replicates, respectively, puzzling steps, are given for nodes that occurred in all applied methods of tree reconstruction.

cisternasii from all other taxa (Fig. 4), which again split into two sub-clades. One comprised Alytes muletensis, Alytes obstetricans maurus, and Alytes dickhilleni, the other comprised all other A. obstetricans subspecies. Consequently, A. obstetricans appeared to be nonmonophyletic. Within Bombina, NJ and QP results showed grouping of the Asian taxa (Bombina orientalis and Bombina maxima, Fig. 5). Moreover, there was a tendency for sister-group relations between Bombina bombina and Bombina variegata. Within the latter, Bombina variegata pachypus was placed basal to the remaining subspecies.

\subsection{Calibration and application of a molecular clock}

The hypothesis of rate constancy within alignment (a) was not rejected by the molecular clock test. Under the Tamura-Nei model of evolution with no molecular clock enforced, the likelihood $(\log L=-3401.06)$ was not significantly better at the $5 \%$ level than with the molecular clock enforced $(\log L=-3416.86)$. Therefore, calculation of divergence times from genetic distances across genera was justified.

Calibrations based on different splits yielded alternative temporal settings for the evolution of taxa. 


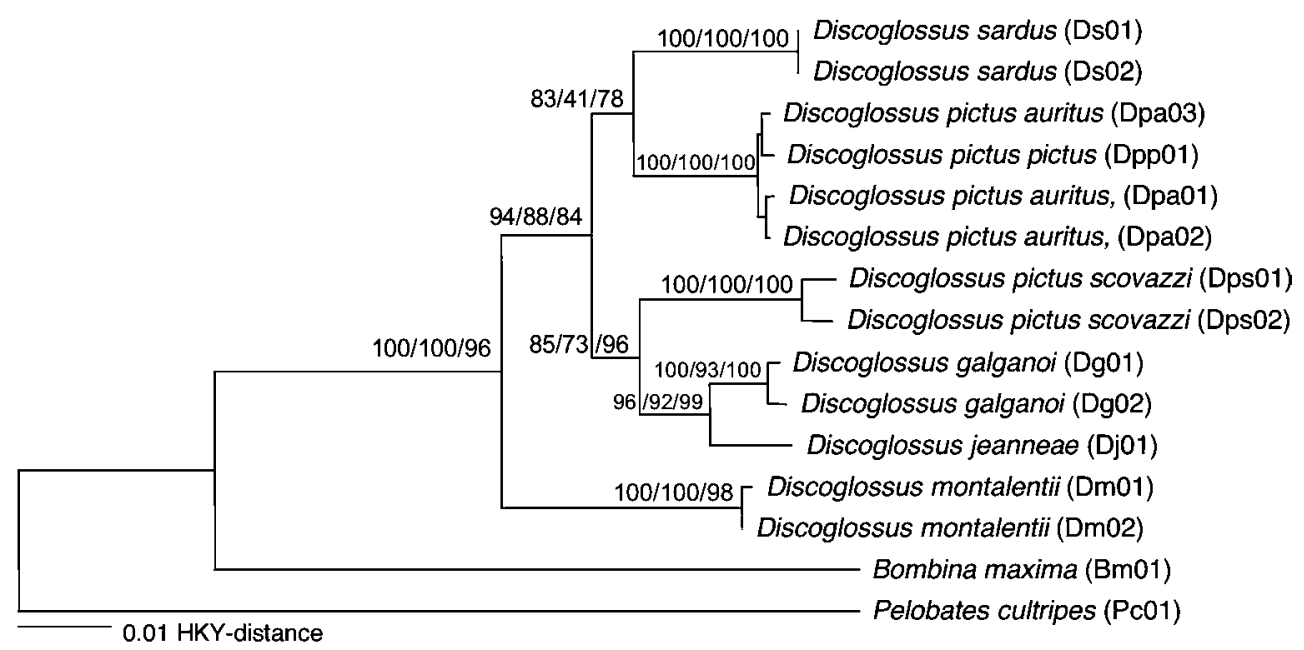

Fig. 3. NJ tree of Discoglossus, based on $909 \mathrm{bp}$ of $16 \mathrm{~S}$ and $12 \mathrm{~S}$ (alignment b) with Pelobates cultripes defined as the outgroup; NJ/MP/QP support values (\%) for 2000 bootstrap replicates, respectively, puzzling steps, are given for nodes that occurred in all applied methods of tree reconstruction.

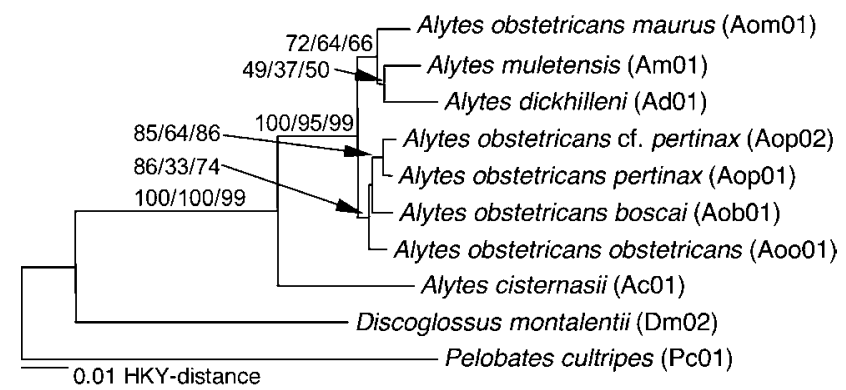

Fig. 4. NJ tree of Alytes, based on $879 \mathrm{bp}$ of $16 \mathrm{~S}$ and $12 \mathrm{~S}$ (alignment c) with Pelobates cultripes defined as the outgroup; NJ/MP/QP support values (\%) for 2000 bootstrap replicates, respectively, puzzling steps, are given for nodes that occurred in all applied methods of tree reconstruction.
Tamura-Nei distances (according to the chosen substitution model) and estimated divergence times are given in Table 3 for selected taxa.

\subsection{Plausibility of scenarios}

Regarding alternative calibrations, varying numbers of estimated divergence times could be explained by known paleogeographic events (Table 3). The scenario based on calibration III showed the maximum degree of plausibility with no unexplained divergence times.

Fisher's two-tailed exact test yielded but one significant result for pairwise comparisons between the best-fitting scenario and its alternatives (III vs. I, $P=0.2$;

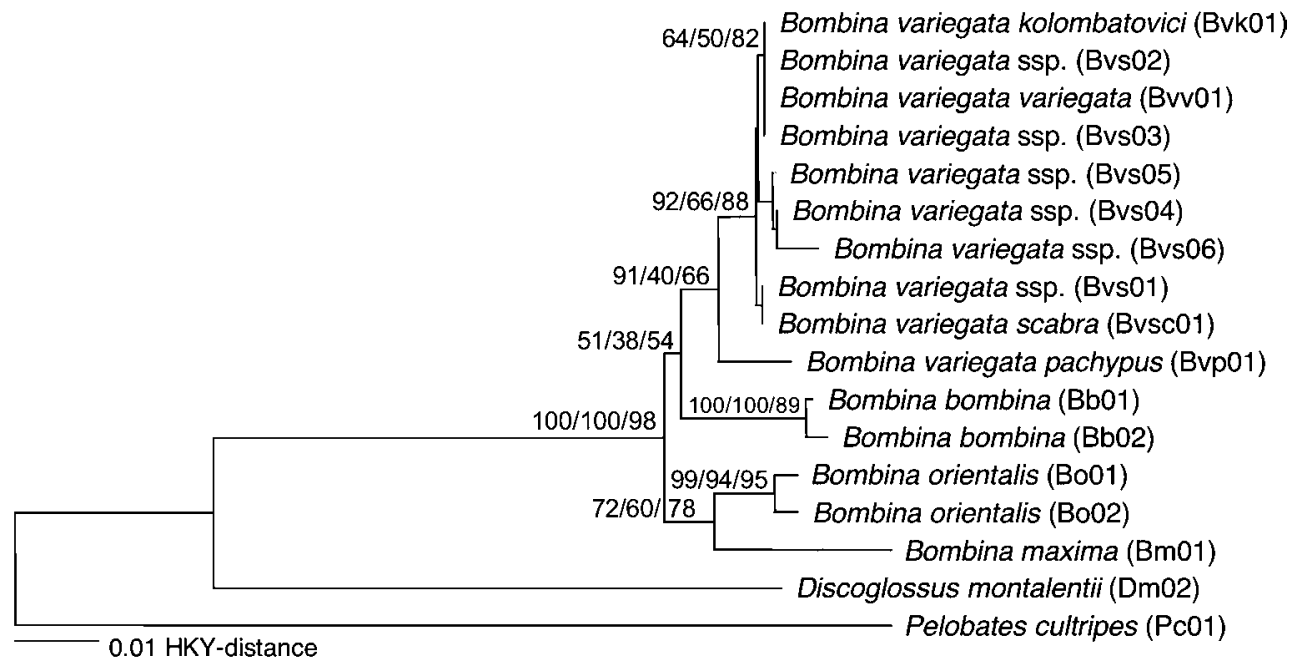

Fig. 5. NJ tree of Bombina, based on 927 bp of $16 \mathrm{~S}$ and $12 \mathrm{~S}$ (alignment d) with Pelobates cultripes defined as the outgroup; NJ/MP/QP support values (\%) for 2000 bootstrap replicates, respectively, puzzling steps, are given for nodes that occurred in all applied methods of tree reconstruction. 


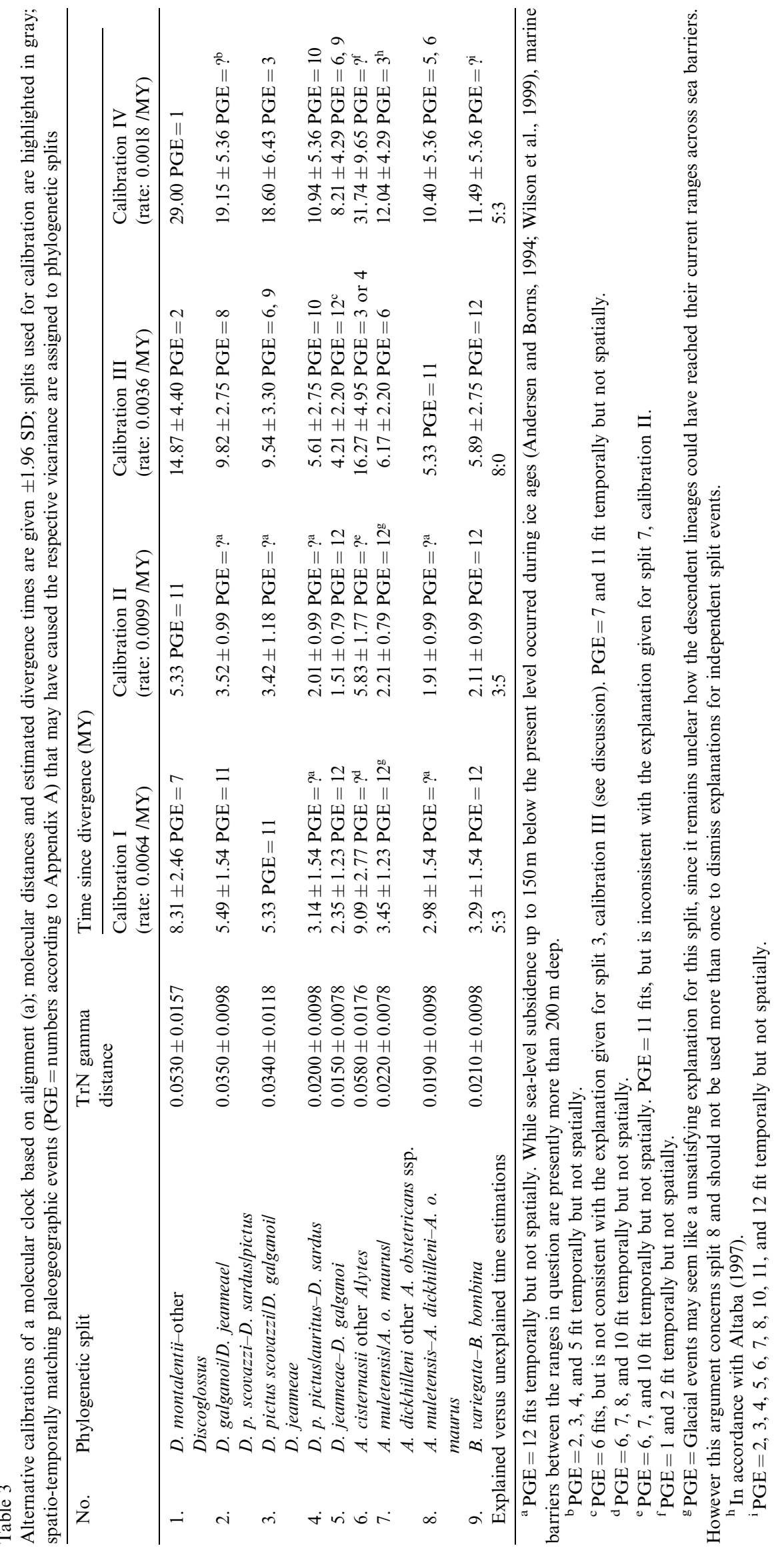


III vs. II, $P=0.03$; and III vs. IV, $P=0.2$ ). This result became non-significant when the critical value $\alpha=0.05$ was Bonferroni-corrected for multiple tests.

\section{Discussion}

Alternative molecular clock calibrations led to competing scenarios for the evolution of Western Mediterranean discoglossid frogs. Some currently accepted and plausible hypotheses for the genera Alytes and Discoglossus proved to be incompatible. One scenario, based on calibration III, completely fitted the paleogeographic data and therefore has considerable appeal. It deserves to be described in more detail below, although statistical testing did not reject the alternatives.

\subsection{Scenario according to calibration III}

Calibration III was based on a hypothesis of Arntzen and García-París (1995, 1997): A. dickhilleni, A. muletensis and A. o. maurus may have become isolated in their current ranges 5.33 MYA after dispersal of an ancestral lineage through a desiccated Mediterranean basin (Fig. 6E). The remaining divergence times within Alytes can also be explained in accordance with the

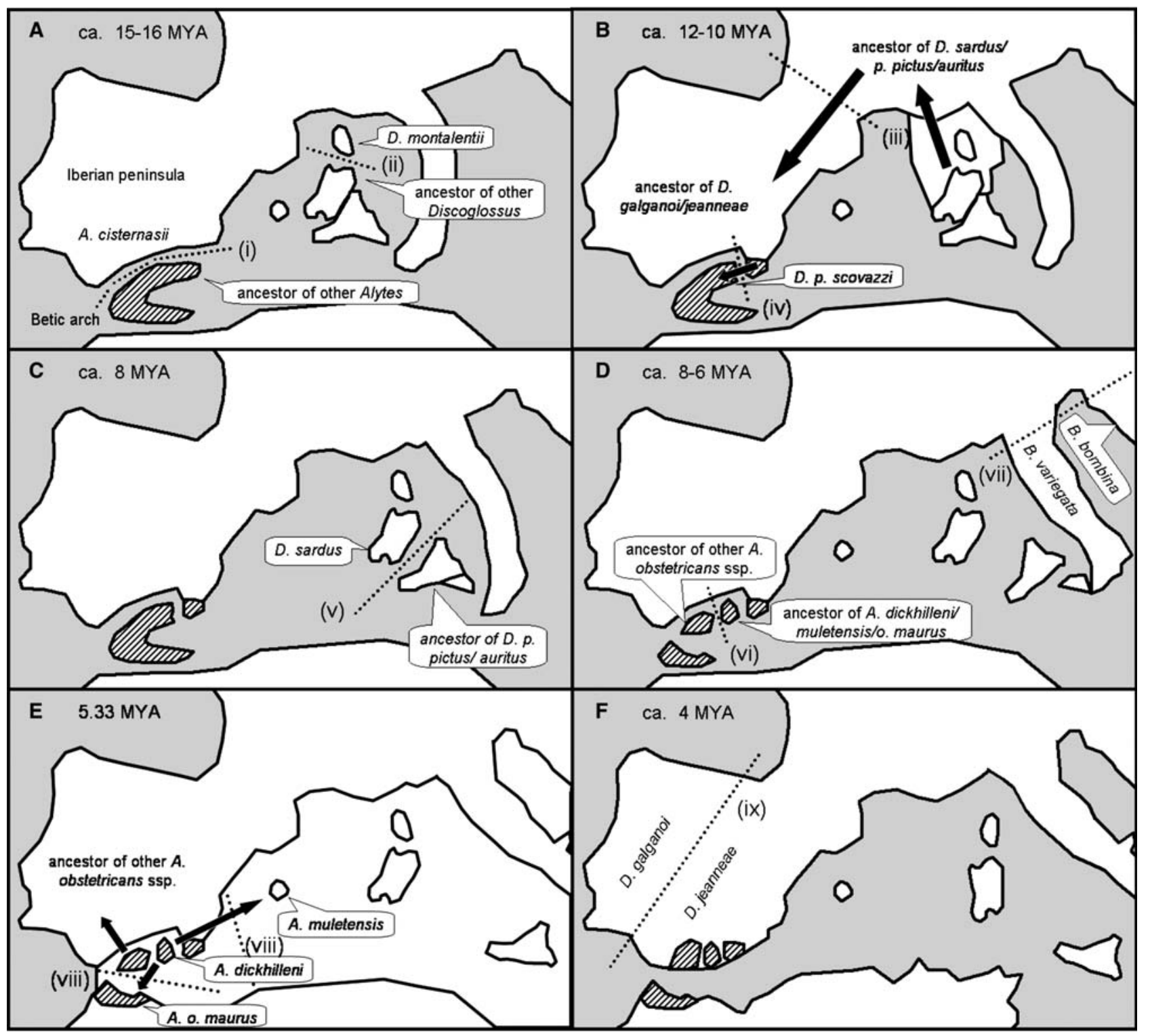

Fig. 6. Paleobiogeographic scenario based on calibration III; arrows indicate assumed dispersal routes; dotted lines denote the following vicariance events: (A) (i) opening of the Betic sea strait and (ii) Corsica-Sardinia rift; (B) (iii) structuring of the Neo-Pyrenees and (iv) fragmentation of the Betic region (hatched); (C) (v) separation of Sardinia from the Calabro-Peloritan massif; (D) (vi) further fragmentation of the Betic region and (vii) restriction to glacial refugia; (E) (viii) sea barriers occurring after the end of the Messinian Salinity Crisis; (F) (ix) restriction to glacial refugia; paleogeographic events are compiled from sources referenced in Appendix A; see text for details. 
above-mentioned authors: opening of the Betic sea strait separated an ancestral lineage that inhabited the insular Betic region (Fig. 6A), and fragmentation of the Betic region isolated A. obstetricans, which later colonized the continent (Figs. 6D and E). Within Discoglossus, an estimated age of ca. 15 million years (MY) for $D$. montalentii matches the Corsica-Sardina rift 2015 MYA (Fig. 6A; Alvarez et al., 1974; Orsini et al., 1980), rather than the separation of the Corsica-Sardinia microplate from the continent ca. 29 MYA (Bellon et al., 1977) as suggested by Capula et al. (1985). In this case, and based on the phylogenetic relationships within the genus, one has to assume that a Sardinian sister taxon of $D$. montalentii later colonized the continent (Fig. 6B) via a land bridge (Orszag-Sperber et al., 1993). Divergence of an Iberian lineage (D. p. scovazzi, D. galganoi, and D. jeanneae; Fig. 6B) may have been caused by the structuring of the Neo-Pyrenees around 10 MYA. The separation of the African D. p. scovazzi from the Iberian taxa (D. galganoilD. jeanneae) may be explained by the fragmentation of the Betic region (Fig. 6B). In this context it has to be noted that secondary contact between the Betic region and the continent is likely to have occurred ca. 10-7 MYA due to crustal narrowing in the eastern Betic sea strait (Lonergan and White, 1997; Weijermars, 1988). Based on the previous explanation, we have to assume an Iberian range of the $D$. galganoilD. jeanneae ancestor. Hence the split between D. galganoi and D. jeanneae can be accounted for by isolation in separate glacial refuges (Fig. 6F), rather than by tectonics in the Betic region (see García-París and Jockusch, 1999).

The divergence of $D$. p. pictus/D. p. auritus and $D$. sardus matches the separation of the Calabro-Peloritan massif (presently Sicily and south Italy) from Sardinia (Duermeijer et al., 1998; Fig. 6C). The split between $B$. bombina and $B$. variegata can be explained in accordance with Szymura (1993) by glaciations and their effect on the overall climate in the Northern Hemisphere (Fig. 6D).

\subsection{Comparison with documented rates of protein evolu- tion}

To further consider the plausibility of alternative scenarios, an independent criterion comes from the comparison of estimated rates of protein evolution based on calibrations I-IV with previously published rates.

According to Avise and Aquadro (1982), vertebrate protein evolution rates range from $0.7 \mathrm{MY} / 1 D_{\mathrm{Nei}}$ (mammalians) up to $18 \mathrm{MY} / 1 D_{\mathrm{Nei}}$ (reptiles). For amphibians, rates between 8 and $10 \mathrm{MY} / 1 D *_{\text {Nei }}$ (Beerli et al., 1996) and $14 \mathrm{MY} / 1 D_{\mathrm{Nei}}$ (Maxson and Maxson, 1979) have been reported ( $D *_{\text {Nei }}$ represents Nei's, 1972 genetic distance, $D_{\mathrm{Nei}}$, as modified by Hillis, 1984), which makes no relevant difference in this case; Beerli et al., 1996). Using documented $D_{\mathrm{Nei}}$ distances within Discoglossus (Lanza et al., 1987), Alytes (Arntzen and García-París, 1995), and Bombina (Szymura, 1983), rates of allozyme evolution can be estimated based on calibrations I-IV (Table 4).

Differences between genera may indicate that (i) $D_{\mathrm{Nei}}$ distances did not evolve at a constant rate, or (ii) methodological differences existed between laboratories (Veith, 1996). In any case, rates of allozyme evolution based on calibration IV are outside the range of documented values, which argues against calibration IV.

\subsection{Evidence from the fossil record}

Despite numerous fossil records of Alytes, Discoglossus and Bombina (Rocek and Rage, 2000; Sanchíz, 1998), there is little evidence relevant to the present study. Morphological differentiation within genera is subtle, so that most fossil remains cannot be assigned to species or lineages with sufficient confidence. According to Sanchíz (1998), fossil specimens of B. bombina and questionable $B$. variegata remains are known from the Pliocene (5.3-1.8 MYA). Depending on our calibrations, the divergence time of these species was dated between 2.1 and 11.5 MYA. Since fossils can only indicate the minimum age of lineages, none of the scenarios discussed above can be ruled out on these grounds.

\subsection{Constraints and perspectives of the presented method}

In this study, we applied a formalized procedure for comparing biogeographic hypotheses, which did not allow us to reject alternative interpretations in the present case. While this conservatism may be perceived as a drawback of the method, we are inclined to see it

Table 4

Rates of allozyme evolution estimated from calibrations I-IV $( \pm \mathrm{SD})$

\begin{tabular}{|c|c|c|c|c|c|}
\hline \multirow[t]{2}{*}{ Taxa } & \multirow[t]{2}{*}{$D_{\mathrm{Nei}}$ distance (reference) } & \multicolumn{4}{|c|}{$\begin{array}{l}\text { Estimated rates of allozyme evolution }\left(\mathrm{MY} / 1 D_{\mathrm{Nei}}\right) \text { based on } \\
\text { calibration }\end{array}$} \\
\hline & & I & II & III & IV \\
\hline A. cisternasii-A. obstetricans & 0.72 (Arntzen and García-París, 1995) & $12.6 \pm 2.0$ & $8.1 \pm 1.3$ & $22.6 \pm 3.5$ & $44.1 \pm 6.8$ \\
\hline B. bombina - B. variegata & 0.49 (Szymura, 1983) & $6.7 \pm 1.6$ & $4.3 \pm 1.0$ & $12.0 \pm 2.9$ & $23.5 \pm 5.6$ \\
\hline D. montalentii-D. p. pictus & 0.99 (Lanza et al., 1987) & $8.4 \pm 1.3$ & 5.4 & $15.0 \pm 2.3$ & 29.3 \\
\hline
\end{tabular}


as the affirmation of a pre-existing problem: a high degree of uncertainty is commonly associated with the timing of paleobiogeographic hypotheses. In the absence of an appropriate test, however, one may be inclined to accept any hypothesis that receives some limited support.

On the positive side, identifying a problem is usually a step toward developing a solution. The statistical power of our test, and thus the probability of achieving a significant result, can be improved by including more phylogenetic splits into the analysis. This may be accomplished by using a larger taxa set that includes additional clades, and by using more sequence data to resolve more splits.

When interpreting the results of the test introduced here, one has to acknowledge the possibility that splits may not be explained by chance with equal probability across all time frames. If, for example, the probability of paleogeographic events becoming known to science decreases with increasing age, a bias towards a lower plausibility of older scenarios will result. On the other hand, a temporal fit with paleogeographic events is harder to reject for older estimates of divergence times, since confidence limits broaden temporally when a low rate of sequence evolution is assumed. We cannot assess quantitatively to which extent these opposed biases may balance each other.

\section{Conclusions}

Estimating dates of lineage divergence remains a difficult task in phylogenetic studies. Where potential calibration points for a molecular clock are not trustworthy a priori, we recommend using them separately for independent calibrations and comparing the resulting scenarios with an appropriate test.

Our results demonstrate that it is not necessarily justified to regard a paleogeographic scenario as wellconfirmed if estimated divergence times can be explained with known paleogeographic events. This may reflect some major difficulties that paleobiogeography has to face to move beyond the stage of hypothesizing. More comprehensive analyses including numerous split events may provide a perspective on how to tackle this problem in future.

\section{Acknowledgments}

We thank D. Donnaire, A. Kiefer, K.-D. Kühnel, R. Malkmus, J.F. Schmidtler, and D.R. Vieites who provided tissue samples. Thanks to the 'paper club' for fruitful discussions, to Renata Platenberg for linguistic assistance, and to two anonymous reviewers who provided valuable comments and suggestions.

\section{Appendix A. Dated paleogeographic events (PGE) in the Western Mediterranean; MYA = million years ago}

\begin{tabular}{|c|c|c|}
\hline No. & MYA & Description of event (references) \\
\hline 1 & 29 & $\begin{array}{l}\text { Separation of the Corsica-Sardinia microplate from the continent (Bellon et al., 1977; Orsini } \\
\text { et al., 1980). }\end{array}$ \\
\hline 2 & $20-15$ & Separation of Corsica from Sardinia (Alvarez et al., 1974; Orsini et al., 1980). \\
\hline 3 & $16-14$ & $\begin{array}{l}\text { Opening of the Betic sea strait separated the south Iberian Betic region from the continent } \\
\text { (Bustillo and Lópes García, 1997; Lonergan and White, 1997). }\end{array}$ \\
\hline 4 & ca. 16 & Large inland saline lakes formed on the Iberian Peninsula (Altaba, 1997). \\
\hline 5 & ca. 15 & $\begin{array}{l}\text { A land bridge, which presumably connected Mallorca and the Betic region, was disrupted at } \\
\text { the Langhian-Serravallian transition (Fontboté et al., 1990). }\end{array}$ \\
\hline 6 & $12-6$ & $\begin{array}{l}\text { Fragmentation of the insular Betic region gave rise to several smaller islands. The south- } \\
\text { western part eventually joined North Africa (Rif Mountains) (Guerra-Merchán and } \\
\text { Serrano, 1993; López Martinez, 1989; Weijermars, 1988). }\end{array}$ \\
\hline 7 & $11.5-6$ & $\begin{array}{l}\text { A land bridge of unspecified duration connected Corsica, Sardinia and the continent during } \\
\text { this period (Orszag-Sperber et al., 1993). }\end{array}$ \\
\hline 8 & ca. 10 & Final structuring of the Neo-Pyrenees (Oosterbroek and Arntzen, 1992). \\
\hline 9 & $10-7$ & $\begin{array}{l}\text { Secondary contact between the Betic region and the continent occurred due to crustal } \\
\text { shortening in the prebetic zone (eastern part of the Betic sea strait) (Lonergan and White, } \\
\text { 1997; Weijermars, 1988). }\end{array}$ \\
\hline 10 & $8.6-7.6$ & $\begin{array}{l}\text { The Calabro-Peloritan massif (presently Sicily and south Italy) broke off from Sardinia and } \\
\text { started to drift eastwards (Duermeijer et al., 1998). }\end{array}$ \\
\hline 11 & 5.33 & $\begin{array}{l}\text { End of the Messinian Salinity Crisis: The formerly dried out Mediterranean basin refilled } \\
\text { after the opening of the Strait of Gibraltar so that land bridges between Europe, Africa and } \\
\text { several islands became flooded (Krijgsman et al., 1999). }\end{array}$ \\
\hline
\end{tabular}


Appendix A (continued)

\begin{tabular}{lll}
\hline No. & MYA & Description of event (references) \\
\hline 12 & $3.4-0.01$ & Ice ages brought about dramatic climatic changes and considerable sea-level subsidence (up \\
& & to 150 m below the present level). Glacial maxima in the Northern Hemisphere at 3.4, 2.4 \\
& & and 0.7 MYA have most often been invoked to explain vicariance events in European \\
& & amphibians (Andersen and Borns, 1994; Müller, 1985; Wilson et al., 1999).
\end{tabular}

Appendix B. Sample list; nomenclature after Frost (2000); ZFMK = Zool. Forschungsinstitut und Museum Alexander Koenig, Bonn

\begin{tabular}{|c|c|c|c|c|c|}
\hline Taxon & Sample locality & $N$ & Haplotype & Voucher & $\begin{array}{l}\text { GenBank } \\
\text { Accession } \\
\text { Nos. 12S, } 16 \mathrm{~S}\end{array}$ \\
\hline Alytes cisternasii & Abela, Portugal & 1 & Ac01 & ZFMK 76720 & $\begin{array}{l}\text { AY333670, } \\
\text { AY333708 }\end{array}$ \\
\hline Alytes dickhilleni & $\begin{array}{l}\text { Parejo, near Sierra } \\
\text { Nevada, Spain }\end{array}$ & 1 & Ad01 & $\begin{array}{l}\text { Voucher not } \\
\text { preserved }\end{array}$ & $\begin{array}{l}\text { AY333672, } \\
\text { AY333710 }\end{array}$ \\
\hline Alytes muletensis & Mallorca & 2 & Am01 & ZFMK 44683 & $\begin{array}{l}\text { AY333671, } \\
\text { AY333709 }\end{array}$ \\
\hline $\begin{array}{l}\text { Alytes obstetricans } \\
\text { pertinax }\end{array}$ & Valencia, Spain & 1 & Aop01 & $\begin{array}{l}\text { Voucher not } \\
\text { preserved }\end{array}$ & $\begin{array}{l}\text { AY333667, } \\
\text { AY333705 }\end{array}$ \\
\hline $\begin{array}{l}\text { Alytes obstetricans } \\
\text { cf. } \\
\quad \text { pertinax }\end{array}$ & $\begin{array}{l}\text { Rabagao near } \\
\text { Pisoes, Portugal }\end{array}$ & 1 & Aop02 & $\begin{array}{l}\text { Voucher not } \\
\text { preserved }\end{array}$ & $\begin{array}{l}\text { AY333666, } \\
\text { AY333704 }\end{array}$ \\
\hline $\begin{array}{l}\text { Alytes obstetricans } \\
\quad \text { boscai }\end{array}$ & Sortelha, Portugal & 1 & Aob01 & ZFMK 76721 & $\begin{array}{l}\text { AY333669, } \\
\text { AY333707 }\end{array}$ \\
\hline $\begin{array}{l}\text { Alytes obstetricans } \\
\quad \text { maurus }\end{array}$ & $\begin{array}{l}\text { Rif-mountains, } \\
\text { Morocco }\end{array}$ & 1 & Aom01 & $\begin{array}{l}\text { Voucher not } \\
\text { preserved }\end{array}$ & $\begin{array}{l}\text { AY333637, } \\
\text { AY333711 }\end{array}$ \\
\hline $\begin{array}{l}\text { Alytes obstetricans } \\
\text { obstetricans }\end{array}$ & $\begin{array}{l}\text { Argelès-sur-Mer, } \\
\text { France }\end{array}$ & 2 & Aoo01 & ZFMK 76716 & $\begin{array}{l}\text { AY333668, } \\
\text { AY333706 }\end{array}$ \\
\hline Bombina bombina & $\begin{array}{l}\text { Lüchow-Dannenberg, } \\
\text { Germany }\end{array}$ & 2 & $\begin{array}{l}\mathrm{Bb} 01 \\
\mathrm{Bb} 02\end{array}$ & $\begin{array}{l}\text { ZFMK 76717; } \\
76718\end{array}$ & $\begin{array}{l}\text { AY333657, } \\
\text { AY333695; } \\
\text { AY333663, } \\
\text { AY333701 }\end{array}$ \\
\hline Bombina maxima & Pet trade & 2 & $\mathrm{Bm} 01$ & $\begin{array}{l}\text { Vouchers not } \\
\text { preserved }\end{array}$ & $\begin{array}{l}\text { AY333659, } \\
\text { AY333697 }\end{array}$ \\
\hline Bombina orientalis & Pet trade & 3 & $\begin{array}{l}\text { Bo01; } \\
\text { Bo02 }\end{array}$ & $\begin{array}{l}\text { Vouchers not } \\
\text { preserved }\end{array}$ & $\begin{array}{l}\text { AY333658, } \\
\text { AY333696; } \\
\text { AY333660, } \\
\text { AY333698 }\end{array}$ \\
\hline Bombina variegatassp. & $\begin{array}{l}\text { Bjeljasnica near Saraj- } \\
\text { evo, Bosnia-Hrzg. }\end{array}$ & 1 & Bvk01 & $\begin{array}{l}\text { Private collection } \\
\text { of J.F. Schmidtler }\end{array}$ & $\begin{array}{l}\text { AY333653, } \\
\text { AY333691 }\end{array}$ \\
\hline Bombina variegata ssp. & $\begin{array}{l}\text { Trebistovo near } \\
\text { Posusje, Bosnia-Hrzg. }\end{array}$ & 1 & Bvs01 & $\begin{array}{l}\text { Private collection } \\
\text { of J.F. Schmidtler }\end{array}$ & $\begin{array}{l}\text { AY333654, } \\
\text { AY333692 }\end{array}$ \\
\hline Bombina variegata ssp. & $\begin{array}{l}\text { Zepce/Bosna valley, } \\
\text { Bosnia-Hrzg. }\end{array}$ & 1 & Bvs02 & $\begin{array}{l}\text { Private collection } \\
\text { of J.F. Schmidtler }\end{array}$ & $\begin{array}{l}\text { AY333655, } \\
\text { AY333693 }\end{array}$ \\
\hline Bombina variegata ssp. & $\begin{array}{l}\text { Mirna valley/Istrien, } \\
\text { Croatia }\end{array}$ & 1 & Bvs03 & $\begin{array}{l}\text { Private collection } \\
\text { of J.F. Schmidtler }\end{array}$ & $\begin{array}{l}\text { AY333665, } \\
\text { AY333703 }\end{array}$ \\
\hline Bombina variegata ssp. & $\begin{array}{l}\text { Gornja Brela/ } \\
\text { Biokovo/Pr. } \\
\text { Makarska, Croatia }\end{array}$ & 1 & Bvk01 & $\begin{array}{l}\text { Private collection } \\
\text { of J.F. Schmidtler }\end{array}$ & $\begin{array}{l}\text { AY333653, } \\
\text { AY333691 }\end{array}$ \\
\hline
\end{tabular}


Appendix B (continued)

\begin{tabular}{|c|c|c|c|c|c|}
\hline Taxon & Sample locality & $N$ & Haplotype & Voucher & $\begin{array}{l}\text { GenBank } \\
\text { Accession } \\
\text { Nos. 12S, 16S }\end{array}$ \\
\hline Bombina variegata ssp. & $\begin{array}{l}\text { Metsovo, } \\
\text { Pindus-mountains, } \\
\text { Greece }\end{array}$ & 2 & $\begin{array}{l}\text { Bvs04; } \\
\text { Bvs05 }\end{array}$ & $\begin{array}{l}\text { Private collection } \\
\text { of J.F. Schmidtler }\end{array}$ & $\begin{array}{l}\text { AY333662, } \\
\text { AY333700; } \\
\text { AY333687, } \\
\text { AY333725 }\end{array}$ \\
\hline Bombina variegata ssp. & $\begin{array}{l}\text { Smolikas mountains, } \\
\text { Greece }\end{array}$ & 1 & Bvs06 & $\begin{array}{l}\text { Voucher not } \\
\text { preserved }\end{array}$ & $\begin{array}{l}\text { AY333688, } \\
\text { AY333726 }\end{array}$ \\
\hline $\begin{array}{l}\text { Bombina variegata } \\
\text { pachypus }\end{array}$ & Italy & 1 & Bvp01 & $\begin{array}{l}\text { Voucher not } \\
\text { preserved }\end{array}$ & $\begin{array}{l}\text { AY333656, } \\
\text { AY333694 }\end{array}$ \\
\hline $\begin{array}{l}\text { Bombina variegata } \\
\text { scabra }\end{array}$ & Kotor, Montenegro & 1 & Bvsc01 & ZFMK 76719 & $\begin{array}{l}\text { AY333661, } \\
\text { AY333699 }\end{array}$ \\
\hline $\begin{array}{l}\text { Bombina variegata } \\
\text { kolombatovici }\end{array}$ & $\begin{array}{l}\text { Mosor mountain near } \\
\text { Split, Croatia }\end{array}$ & 1 & Bvk01 & $\begin{array}{l}\text { Private collection } \\
\text { of J.F. Schmidtler }\end{array}$ & $\begin{array}{l}\text { AY333653, } \\
\text { AY333691 }\end{array}$ \\
\hline $\begin{array}{l}\text { Bombina variegata } \\
\text { variegata }\end{array}$ & Mt. Baldo, Italy & 2 & Bvv01 & $\begin{array}{l}\text { Vouchers not } \\
\text { preserved }\end{array}$ & $\begin{array}{l}\text { AY333664, } \\
\text { AY333702 }\end{array}$ \\
\hline $\begin{array}{l}\text { Discoglossus } \\
\text { galganoi }\end{array}$ & Carregosa, Spain & 1 & $\operatorname{Dg} 01$ & $\begin{array}{l}\text { Voucher not } \\
\text { preserved }\end{array}$ & $\begin{array}{l}\text { AY333680, } \\
\text { AY333718 }\end{array}$ \\
\hline $\begin{array}{l}\text { Discoglossus } \\
\text { galganoi }\end{array}$ & Monchique, Spain & 1 & $\mathrm{Dg} 02$ & $\begin{array}{l}\text { Voucher not } \\
\text { preserved }\end{array}$ & $\begin{array}{l}\text { AY333681, } \\
\text { AY333719 }\end{array}$ \\
\hline $\begin{array}{l}\text { Discoglossus } \\
\text { jeanneae }\end{array}$ & Facinas, Spain & 1 & Dj01 & $\begin{array}{l}\text { Voucher not } \\
\text { preserved }\end{array}$ & $\begin{array}{l}\text { AY333682, } \\
\text { AY333720 }\end{array}$ \\
\hline $\begin{array}{l}\text { Discoglossus } \\
\text { jeanneae }\end{array}$ & $\begin{array}{l}\text { Rio Verde near } \\
\text { Marbella, Spain }\end{array}$ & 1 & Dj01 & $\begin{array}{l}\text { Voucher not } \\
\text { preserved }\end{array}$ & $\begin{array}{l}\text { AY333682, } \\
\text { AY333720 }\end{array}$ \\
\hline $\begin{array}{l}\text { Discoglossus } \\
\quad \text { montalentii }\end{array}$ & Porto, Corsica & 2 & Dm01 & $\begin{array}{l}\text { Vouchers not } \\
\text { preserved }\end{array}$ & $\begin{array}{l}\text { AY333676, } \\
\text { AY333714 }\end{array}$ \\
\hline $\begin{array}{l}\text { Discoglossus } \\
\quad \text { montalentii }\end{array}$ & Vizzavona, Corsica & 1 & Dm01 & $\begin{array}{l}\text { Voucher not } \\
\text { preserved }\end{array}$ & $\begin{array}{l}\text { AY333676, } \\
\text { AY333714 }\end{array}$ \\
\hline $\begin{array}{l}\text { Discoglossus } \\
\quad \text { montalentii }\end{array}$ & Bonifacio, Corsica & 1 & $\mathrm{Dm} 02$ & $\begin{array}{l}\text { Voucher not } \\
\text { reserved }\end{array}$ & $\begin{array}{l}\text { AY333677, } \\
\text { AY333715 }\end{array}$ \\
\hline $\begin{array}{l}\text { Discoglossus } \\
\text { pictus auritus }\end{array}$ & Tunisia & 2 & $\begin{array}{l}\text { Dpa01; } \\
\text { Dpa02 }\end{array}$ & $\begin{array}{l}\text { Vouchers not } \\
\text { preserved }\end{array}$ & $\begin{array}{l}\text { AY333683, } \\
\text { AY333721; } \\
\text { AY333684, } \\
\text { AY333722 }\end{array}$ \\
\hline $\begin{array}{l}\text { Discoglossus } \\
\quad \text { pictus auritus }\end{array}$ & $\begin{array}{l}\text { Argelès-sur-Mer, } \\
\text { France }^{\mathrm{a}}\end{array}$ & 2 & Dpa03 & $\begin{array}{l}\text { ZFMK 76714; } \\
76715\end{array}$ & $\begin{array}{l}\text { AY } 333685 \\
\text { AY333723 }\end{array}$ \\
\hline $\begin{array}{l}\text { Discoglossus } \\
\text { pictus pictus }\end{array}$ & Malta & 1 & Dpp01 & $\begin{array}{l}\text { Voucher not } \\
\text { preserved }\end{array}$ & $\begin{array}{l}\text { AY333686, } \\
\text { AY333724 }\end{array}$ \\
\hline $\begin{array}{l}\text { Discoglossus pictus } \\
\text { scovazzi }\end{array}$ & $\begin{array}{l}\text { Ceuta, Spanish } \\
\text { enclave in North } \\
\text { Africa }\end{array}$ & 3 & $\begin{array}{l}\text { Dps01; } \\
\text { Dps02 }\end{array}$ & $\begin{array}{l}\text { Vouchers not } \\
\text { preserved }\end{array}$ & $\begin{array}{l}\text { AY333678, } \\
\text { AY333716; } \\
\text { AY333679, } \\
\text { AY333717 }\end{array}$ \\
\hline $\begin{array}{l}\text { Discoglossus } \\
\text { sardus }\end{array}$ & Ajaccio, Corsica & 1 & Ds01 & $\begin{array}{l}\text { Voucher not } \\
\text { preserved }\end{array}$ & $\begin{array}{l}\text { AY333674, } \\
\text { AY333712 }\end{array}$ \\
\hline $\begin{array}{l}\text { Discoglossus } \\
\text { sardus }\end{array}$ & Ill Rousse, Corsica & 1 & Ds02 & $\begin{array}{l}\text { Voucher not } \\
\text { preserved }\end{array}$ & $\begin{array}{l}\text { AY } 333675 \\
\text { AY333713 }\end{array}$ \\
\hline $\begin{array}{l}\text { Discoglossus } \\
\quad \text { sardus }\end{array}$ & Cap Corse, Corsica & 1 & Ds02 & $\begin{array}{l}\text { Voucher not } \\
\text { preserved }\end{array}$ & $\begin{array}{l}\text { AY333675, } \\
\text { AY333713 }\end{array}$ \\
\hline Pelobates cultripes & $\begin{array}{l}\text { Playa de la Lanzada, } \\
\text { Spain }\end{array}$ & 1 & Pc01 & $\begin{array}{l}\text { Voucher not } \\
\text { preserved }\end{array}$ & $\begin{array}{l}\text { AY333651, } \\
\text { AY333689 }\end{array}$ \\
\hline Pipa parva & Pet trade & 1 & Pp01 & ZFMK 76722 & $\begin{array}{l}\text { AY333652, } \\
\text { AY333690 }\end{array}$ \\
\hline
\end{tabular}

${ }^{\mathrm{a}}$ Introduced from Africa (Martens and Veith, 1987). 


\section{Appendix C. Taxonomic conclusions}

Discoglossus pictus is not a monophyletic unit. The taxon D. pictus scovazzi turns out to be a highly differentiated genetic lineage, the sister-group of which contains the Iberian species $D$. galganoi and $D$. jeanneae (Figs. 2 and 3). Some doubt regarding monophyly of $D$. pictus has already been raised by García-París and Jockusch (1999). D. p. scovazzi should therefore be assigned species rank.

Alytes obstetricans appears to be a non-monophyletic unit. The taxon A. obstetricans maurus turns out to be as equally differentiated as the species $A$. muletensis and $A$. dickhilleni. According to a strong tendency, these three taxa form a monophyletic group (Figs. 2 and 4). A. obstetricans maurus is therefore a candidate for assignment of species rank.

Based on allozyme data, Nascetti et al. (1986) found no differentiation between $D$. pictus auritus and D. pictus pictus. This interpretation is supported by similar findings in the present study (Figs. 2 and 3), which leads to the conclusion that $D$. p. auritus is not a valid subspecies.

\section{References}

Altaba, C.R., 1997. Phylogeny and biogeography of midwife toads (Alytes, Discoglossidae): a reappraisal. Contrib. Zool. 66, 257-262.

Alvarez, W., Cocozza, T., Wezel, F.C., 1974. Fragmentation of the Alpine orogenic belt by microplate dispersal. Nature 248, 309-314.

Andersen, B.G., Borns, H.W., 1994. The Ice Age World. Scandinavia University Press, Oslo.

Arntzen, J.W., 1978. Some hypotheses on postglacial migrations of the fire-bellied toad, Bombina bombina (Linnaeus) and the yellowbellied toad, Bombina variegata (Linnaeus). J. Biogeogr. 5, 339345.

Arntzen, J.W., García-París, M., 1995. Morphological and allozyme studies of midwife toads (genus Alytes) including the description of two new taxa from Spain. Contrib. Zool. 65 (1), 5-34.

Arntzen, J.W., García-París, M., 1997. Phylogeny and biogeography of midwife toads (Alytes, Discoglossidae): a rebuttal. Contrib. Zool. 66, 263-268.

Avise, J.C., Aquadro, C.F., 1982. A comparative summary of genetic distances in the vertebrates. Evol. Biol. 15, 151-158.

Beerli, P., Hotz, H., Uzzell, T., 1996. Geologically dated sea barriers calibrate a protein clock for Aegean water frogs. Evolution 50, 1676-1687.

Bellon, H., Coulon, C., Edel, J.B., 1977. Le dé placement de la Sardaigne. Synthèse des donnees géochronologiques, magnetiques et paléomagnétiques. Bull. Soc. Geol. Fr. 7, 825-831.

Blondel, J., Aronson, J., 1999. Biology and Wildlife of the Mediterranean Region. Oxford University Press, New York.

Broughton, R.E., Stanley, S.E., Durrett, R.T., 2000. Quantification of homoplasy for nucleotide transitions and transversions and a reexamination of assumptions in weighted phylogenetic analysis. Syst. Biol. 49, 617-627.

Busack, S.D., 1986. Biochemical and morphological differentiation in Spanish and Moroccan populations of Discoglossus and the description of a new species from Southern Spain (Amphibia, Anura, Discoglossidae). Ann. Carnegie Mus. 55 (3), 41-61.
Bustillo, M.A., Lópes García, M.J., 1997. Age, distribution and composition of Miocene diatom bearing sediments in the Guadalquivir Basin, Spain. Geobios 30 (3), 335-350.

Capula, M., Nascetti, G., Lanza, B., Bullini, L., Crespo, E.G., 1985. Morphological and genetic differentiation between the Iberian and the other West Mediterranean Discoglossus species (Amphibia, Salientia, Discoglossidae). Monit. Zool. Ital. (N.S.) 19, 69-90.

Duermeijer, C.E., van Vugt, N., Langeris, C.G., Meulenkamp, J.E., Zachariasse, N.J., 1998. A major late Tortonian rotation phase in the opening of the Tyrrhenian basin. Tectonophysics 287, 233-249.

Farris, J.S., Källersjö, M., Kluge, A.G., Bult, C., 1994. Testing significance of incongruence. Cladistics 10, 315-319.

Felsenstein, J., 1985. Confidence limits on phylogenies: an approach using the bootstrap. Evolution 39, 783-791.

Fontboté, J.M., Guimerà, J., Roca, E., Sàbat, F., Santanach, P., Fernández-Ortigosa, F., 1990. The Cenozoic geodynamic evolution of the Valencia trough (Western Mediterranean). Rev. Soc. Geol. Esp. 3, 249-259.

Ford, L., Cannatella, D., 1993. The major clades of frogs. Herpetol. Monogr. 7, 94-117.

Frost, D.R., 2000. Amphibian species of the world: An online reference, V.2.20. Available from: http://www.research.amnh.org/ herpetology/amphibia/index.html.

García-París, M., Jockusch, E.L., 1999. A mitochondrial DNA perspective on the evolution of Iberian Discoglossus (Amphibia: Anura). J. Zool. 248 (2), 209-218.

Gasc, J.P., Cabela, A., Crnobrnja-Isailovic, J., Dolmen, D., Grossenbacher, K., Haffner, P., Lescure, J., Martens, H., Martínez Rica, J.P., Maurin, H., Oliveira, M.E., Sofianidou, T.S., Veith, M., Zuiderwijk, A. (Eds.), 1997. Atlas of Amphibians and Reptiles in Europe. Collection Patrimoines Naturels, Paris.

Goebel, A.M., Donelly, J.M., Atz, M.E., 1999. PCR primers and amplification methods for $12 \mathrm{~S}$ ribosomal DNA, the control region, cytochrome oxidase I, and cytochrome $b$ in bufonids and other frogs and an overview of PCR primers which have amplified DNA in amphibians successfully. Mol. Phylogenet. Evol. 11, 163-199.

Guerra-Merchán, A., Serrano, F., 1993. Tectosedimentary setting and chronostratigraphy of the Neogene reefs in the Almazora Corridor (Betic Cordillera, Spain). Geobios 26, 57-67.

Hasegawa, M., Kishino, H., Yano, T., 1985. Dating the human-ape splitting by a molecular clock of mitochondrial DNA. J. Mol. Evol. $22,160-174$.

Hay, J.M., Ruvinsky, I., Hedges, S.B., Maxson, L.R., 1995. Phylogenetic relationships of amphibian families inferred from DNA sequences of mitochondrial $12 \mathrm{~S}$ and $16 \mathrm{~S}$ ribosomal RNA genes. Mol. Biol. Evol. 12 (5), 928-937.

Heckman, D.S., Geiser, D.M., Eidell, B.R., Stauffer, R.L., Kardos, N.L., Hedges, S.B., 2001. Molecular evidence for the early colonization of land by fungi and plants. Science 293, 1129-1132.

Hedges, S.B., 1992. The number of replicates needed for accurate estimation of the bootstrap $P$ value in phylogenetic studies. Mol. Biol. Evol. 9, 366-369.

Hedges, S.B., Parker, P.H., Sibley, C.G., Kumar, S., 1996. Continental breakup and the ordinal diversification of birds and mammals. Nature 381, 226-229.

Hillis, D.M., 1984. Misuse and modification of Nei's genetic distance. Syst. Zool. 33, 238-240.

Hillis, D.M., Bull, J.J., 1993. An empirical test of bootstrapping as a method for assessing confidence in phylogenetic analysis. Syst. Biol. 42 (2), 182-192.

Hillis, D.M., Mable, B.K., Moritz, C., 1996. Applications of molecular systematics: the state of the field and a look to the future. In: Hillis, D.M., Moritz, C., Mable, B.K. (Eds.), Molecular Systematics, second ed. Sinauer, Sunderland, pp. 515-545.

Huelsenbeck, J.P., Crandall, K.A., 1997. Phylogeny estimation and hypothesis testing using maximum likelihood. Annu. Rev. Ecol. Syst. 28, 437-466. 
Huelsenbeck, J.P., Bull, J.J., Cunningham, C.W., 1996. Combining data in phylogenetic analyses. Trends Ecol. Evol. 11, 152-158.

Krijgsman, W., Hilgen, F.J., Raffi, I., Sierro, F.J., Wilson, D.S., 1999. Chronology, causes and progression of the Messinian salinity crisis. Nature 400, 652-655.

Kumar, S., Tamura, K., Jakobsen, I.B., Nei, M., 2001. MEGA2: molecular evolutionary genetics analysis software. Bioinformatics 17 (12), 1244-1245.

Lanza, B., 1973. Gli Anfibi e i Rettili delle isole circumsiciliane. Lav. Soc. ital. Biogeogr. (N.S.) 3, 755-804.

Lanza, B., Nascetti, G., Capula, M., Bullini, L., 1987. Les Discoglosses de la région méditerranéenne occidentale. Bull. Soc. Herp. Fr. 40, 16-27.

Lonergan, L., White, N., 1997. Origin of the Betic-Rif mountain belt. Tectonics 16 (3), 504-522.

López Martinez, N., 1989. Tendencias en paleogeografía. El futuro de la biogeografía del pasado. In: Aguirre, E. (Ed.), Tendencias en paleontología. CSIC, Madrid, pp. 271-296.

Martens, H., Veith, M., 1987. Considerations on origin and chorology of Discoglossus pictus Otth, 1837 in the eastern Pyrenees. In: Van Gelder, J.J., Strijbosch, H., Bergers, P.J.M. (Eds.), Proceedings of the 4th Ord. Gen. Meeting S.E.H. in Nijmegen 1987, Faculty of Science, Nijmegen, pp. 267-269.

Maxson, L.R., Maxson, R.D., 1979. Comparative albumin and biochemical evolution in plethodontid salamanders. Evolution 33, $1057-1062$.

Maxson, L.R., Szymura, J.M., 1979. Quantitative immunological studies of the albumins of several species of the fire bellied toads, genus Bombina. Comp. Biochem. Physiol. 63B, 517-519.

Maxson, L.R., Szymura, J.M., 1984. Relationships among discoglossid frogs: an albumin perspective. Amphib.-Reptilia 5, 245-252.

Mertens, R., 1928. Zur Naturgeschichte der europäischen Unkenarten (Bombina). Z. Morph. Ökol. Tiere 11, 613-623.

Müller, C., 1985. Late Miocene to recent Mediterranean biostratigraphy and paleoenvironments based on calcareous nannoplankton. In: Stanley, D.J., Wezel, F.-C. (Eds.), Geological Evolution of the Mediterranean Basin. Springer, New York, pp. 458-471.

Nascetti, G., Capula, M., Lanza, B., Bullini, L., 1986. Ricerche elettroforetiche sul genere Discoglossus (Amphibia, Anura, and Discoglossidae). Boll. Zool. 53 (suplemento), 57.

Nei, M., 1972. Genetic distance between populations. Am. Nat. 106, 283-292.

Nei, M., Kumar, S., 2000. Molecular Evolution and Phylogenetics. Oxford University Press, New York.

Oosterbroek, P., Arntzen, J.W., 1992. Area-cladograms of CircumMediterranean taxa in relation to Mediterranean palaeogeography. J. Biogeogr. 19, 3-20.

Orsini, J.B., Coulon, C., Cocozza, T., 1980. Dérive cénozoique de la Corse et de la Sardaigne et ses marqueurs géologiques. Geol. Mijnb. 59, 385-396.

Orszag-Sperber, F., Butterlin, J., Clermonte, J., Colchen, M., Guiraud, R., Poisson, A., Ricou, L.E., 1993. Tortonian Palaeoenvironments (11.5-6 Ma). and map. In: Dercourt, J., Ricou, L.E., Vrielynck, B. (Eds.), Atlas Tethys, Paleoenvironmental Maps. Gauthier-Villars, Paris, pp. 237-239.

Palumbi, S., Martin, A., Romano, S., McMillan, W.-O., Stice, L., Grabowski, G., 1991. The Simple Fool's Guide to PCR, Version 2.0. Department of Zoology and Kewalo Marine Laboratory, University of Hawaii.

Posada, D., Crandall, K.A., 1998. Modeltest: testing the model of DNA substitution. Bioinformatics 14, 817-818.

Rambaut, A., Bromham, L., 1998. Estimating divergence dates from molecular sequences. Mol. Biol. Evol. 15 (4), 422-448.

Rocek, Z., Rage, J.-C., 2000. Tertiary anura of Europe, Africa, Asia, North America and Australia. In: Heatwole, H., Carroll, R.L. (Eds.), Amphibian Biology-Palaeontology. Surrey Beatty and Sons, Chipping Norton, Australia, pp. 1332-1387.
Roe, B.A., Din-Pow, M., Wilson, R.K., Wong, J.F., 1985. The complete nucleotide sequence of the Xenopus laevis mitochondrial genome. J. Biol. Chem. 260, 9759-9774.

Rosenberg, M.S., Kumar, S., 2001. Traditional phylogenetic reconstruction methods reconstruct shallow and deep evolutionary relationships equally well. Mol. Biol. Evol. 18 (9), 1823-1827.

Saitou, N., Nei, M., 1987. The neighbor-joining method: a new method for reconstructing phylogenetic trees. Mol. Biol. Evol. 4, 406-425.

Sanchíz, B., 1998. Salientia. Handbuch der Paläoherpetologie, vol. 4. Friedrich Pfeil, München.

Sanderson, M.J., 1997. A nonparametric approach to estimating divergence times in the absence of rate constancy. Mol. Biol. Evol. 14 (12), 1218-1231.

Schmidt, H.A., Strimmer, K., Vingron, M., von Haeseler, A., 2000. Tree-Puzzle, version 5.0. Heidelberg/Oxford/Leipzig.

Stace, C.A., 1989. Dispersal versus vicariance-no contest. J. Biogeogr. $16,201-202$

Stebbins, R.C., Cohen, N.W., 1995. A Natural History of Amphibians, third ed., 1997. Princeton University Press, Princeton, NJ.

Swofford, D.L., 2001. PAUP*. Phylogenetic Analysis Using Parsimony (* and other Methods), version 4.0b10. Sinauer, Sunderland.

Swofford, D.L., Olsen, G.J., Waddell, P.J., Hillis, D.M., 1996. Phylogenetic inference. In: Hillis, D.M., Moritz, C., Mable, B.K. (Eds.), Molecular Systematics, second ed. Sinauer, Sunderland, pp. 407-514.

Szymura, J.M., 1983. Genetic differentiation between hybridizing species Bombina bombina and Bombina variegata (Salientia, Discoglossidae) in Poland. Amphib.-Reptilia 4, 137-145.

Szymura, J.M., 1988. Regional differentation and hybrid zones between fire-bellied toads Bombia bombina and Bombina variegata in Europe. Rozprawy Habilitacyjne, Uniwersytet Jagiellonski, Cracow.

Szymura, J.M., 1993. Analysis of hybrid zones with Bombina. In: Harrison, R.G. (Ed.), Hybrid Zones and the Evolutionary Process. Oxford University Press, Oxford, pp. 261-289.

Tamura, K., Nei, M., 1993. Estimation of the number of nucleotide substitutions in the control region of mitochondrial DNA in humans and chimpanzee. Mol. Biol. Evol. 10, 512-526.

Thompson, J.D., Gibson, T.J., Plewniak, F., Jeanmougin, F., Higgins, D.G., 1997. The Clustal X windows interface: flexible strategies for multiple sequence alignment aided by quality analysis tools. Nucleic Acids Res. 24, 4876-4882.

Thorne, J.L., Kishino, H., Painter, I.S., 1998. Estimating the rate of evolution of the rate of molecular evolution. Mol. Biol. Evol. 15, $1647-1657$.

Veith, M., 1996. Molecular markers and species delimitation: examples from the European batrachofauna. Amphib.-Reptilia 17, 303-314.

Vences, M., Glaw, F., 1996. Further investigations on Discoglossus bioacoustics: relationships between $D$. galganoi galganoi, D. $g$. jeanneae and D. pictus scovazzi. Amphib.-Reptilia 17, 333-340.

Weijermars, R., 1988. Neogene tectonics in the Western Mediterranean may have caused the Messinian Salinity Crisis and an associated glacial event. Tectonophysics 148, 211-219.

Whelan, S., Liò, P., Goldman, N., 2001. Molecular phylogenetics: state-of-the-art methods for looking into the past. Trends Genet. 17, 262-272.

Wilson, R.C.L., Drury, S.A., Chapman, J.L., 1999. The Great Ice Age. The Open University, London, New York.

Wray, G.A., Levinton, J.S., Shapiro, L.H., 1996. Molecular evidence for deep precambrian divergences among metazoan phyla. Science 274, 568-573.

Zuckerkandl, E., Pauling, L., 1962. Molecular disease, evolution, and genic heterogeneity. In: Kasha, M., Pullman, B. (Eds.), Horizons in Biochemistry. Academic Press, New York, pp. 189-225.

Zuckerkandl, E., Pauling, L., 1965. Evolutionary divergence and convergence in proteins. In: Bryson, V., Vogel, H.J. (Eds.), Evolving Genes and Proteins. Academic Press, New York, pp. 97-166. 